\title{
Molecular differentiation of species of the genus Zungaro (Siluriformes, Pimelodidae) from the Amazon and Paraná-Paraguay River basins in Brazil
}

\author{
T.A. Boni ${ }^{1}$, A.A. Padial ${ }^{2}$, S.M.A.P. Prioli ${ }^{1}$, L.C. Lucio ${ }^{1}$, T.C. Maniglia ${ }^{1}$, \\ T.S. Bignotto ${ }^{1}$, R.S. Panarari-Antunes ${ }^{3}$, R.A. Prioli ${ }^{4}$ and A.J. Prioli ${ }^{1}$ \\ ${ }^{1}$ Núcleo de Pesquisas em Limnologia, Ictiologia e Aquicultura, \\ Universidade Estadual de Maringá, Maringá, PR, Brasil \\ ${ }^{2}$ Departamento de Botânica, \\ Universidade Federal do Paraná, Curitiba, PR, Brasil \\ ${ }^{3}$ Instituto Federal do Paraná, Campus Palmas, Palmas, PR, Brasil \\ ${ }^{4}$ Pós-Graduação em Ciência Animal e Pastagem/Biotecnologia, \\ Escola Superior de Agricultura “Luiz de Queiroz”, \\ Universidade de São Paulo, Piracicaba, SP, Brasil \\ Corresponding author: T.A. Boni \\ E-mail: talgeaiex@gmail.com
}

Genet. Mol. Res. 10 (4): 2795-2805 (2011)

Received January 3, 2011

Accepted July 5, 2011

Published November 10, 2011

DOI http://dx.doi.org/10.4238/2011.November.10.2

\begin{abstract}
Fish species of the Zungaro genus (Siluriformes, Pimelodidae) are amongst the largest migratory fish in Latin America and have considerable economic importance for commercial fishing in Brazil. However, natural populations of this large catfish are experiencing a severe decline. There are significant taxonomical inconsistencies for this fish. Two geographically separated species of the fish were initially described, one endemic in the Amazon and another in the ParanáParaguay River basins. A taxonomic review had recently proposed that there is only one Zungaro species in Brazil, based on morphological data. We made a molecular study of Zungaro populations in an attempt
\end{abstract}


to solve taxonomical inconsistencies and to analyze genetic diversity in natural populations of this genus. We analyzed two regions of the mitochondrial DNA (the control region and the ATPase 6 gene region) of individuals sampled from the Paraná-Paraguay River and Amazon River basins. Analyses based on $p$-distances and maximum likelihood phylogenetic models showed a genetic difference between populations corresponding to different species. Genetic differentiation between Zungaro populations was at the same level as that observed between other Siluriformes species, using the same DNA sequences. We conclude that Zungaro species of the Paraná-Paraguay River basin do not belong to the same species found in the Amazon basin. This finding has a significant implication for conservation of this fish, given that populations are disappearing at a high rate in the Paraná-Paraguay River basin, mainly due to impoundments.

Key words: Mitochondrial DNA; Zungaro; D-loop; ATPase 6

\section{INTRODUCTION}

Fish species of the Zungaro genus (Siluriformes, Pimelodidae) are piscivorous, with external fertilization and usually inhabit deep holes of lotic environments. These catfishes (popularly known as "Jaú" in Brazil) are among the largest species with migratory behavior in Neotropical rivers, reaching up to $150 \mathrm{~kg}$ (330 pounds) in weight and $144 \mathrm{~cm}$ (ca. 4.5 feet) in length (Agostinho et al., 2003). Not surprisingly, they have a great importance on commercial fishing and are highly appreciated for both regional culinary and recreational fishing. However, knowledge of the biology of this fish is still incomplete, particularly as related to its migratory behavior (Agostinho et al., 2003). Meanwhile, natural populations of Zungaro species have recently experienced a severe decline on population size mainly due to the construction of hydropower dams, since they prevent migration (Pelicice and Agostinho, 2008).

Additionally, there are taxonomic inconsistencies in the Zungaro genus in Brazil that can affect conservation of natural populations of this fish. A previous study has described two morphologically distinct species in major Brazilian rivers (Lundberg and Littmann, 2003): the species Zungaro zungaro (Humbolt, 1821), found in the Amazon basin, and the species Zungaro jahu (Ihering, 1898), restricted to the Paraná-Paraguay River basin. Moreover, this is the information available on FishBase (http://www.fishbase.org). Nevertheless, a review suggested that all populations of Zungaro genus in Brazil belonged to the species Z. zungaro (Graça and Pavanelli, 2007). To our knowledge, no previous study was able to morphologically differentiate two species (see Lundberg and Littmann, 2003; López et al., 2005; Britski et al., 2007; Ferraris, 2007; Graça and Pavanelli, 2007). Accordingly, information regarding the two species illustrated in FishBase is not sufficient to differentiate them, considering both morphology and aspects of their behavior (see http://www.fishbase.org).

In this context molecular biology can be useful to clarify the taxonomic status and answer ecological questions related to gene flow in natural populations. Several researchers have used molecular markers to differentiate species (e.g., Torres and Ribeiro, 2009). Mitochondrial DNA (mtDNA) is an effective marker for studies on animal evolution, phylogeography and 
population genetics (Agnese et al., 1997; Rokas et al., 2003; Azevedo et al., 2008; Ortí et al., 2008). Additionally, mtDNA has also been used to differentiate related species (Johns and Avise, 1998). In particular, the control region (D-loop) and the ATPase 6 gene region are among the most frequently used markers for this purpose (Meyer, 1994; Avise, 2004; Prioli et al., 2011).

Therefore, our goal was to molecularly differentiate individuals of Zungaro from the Paraná-Paraguay River and Amazon basins in Brazil. This is essential to solve taxonomic uncertainties and prevent frequent changes on the scientific classification of the species. As a consequence, the almost inexistent information about the genetic diversity of natural populations of Zungaro species was amplified, allowing for proper evaluation of their conservation status in Brazil.

\section{MATERIAL AND METHODS}

Individuals of the Zungaro genus were sampled from the Manso River, located at the Paraná-Paraguay River basin, and the Tocantins River in the Amazon basin (Figure 1). Four and three individuals (from the Paraná-Paraguay River and Amazon basins, respectively) were analyzed for the D-loop region (the control region), whereas 11 and 5 (equally from the Paraná-Paraguay River and Amazon basins, respectively) were analyzed for ATPase 6 gene region. This number of individuals was sufficient for our analyses of molecular differentiation given the results (see Results section).
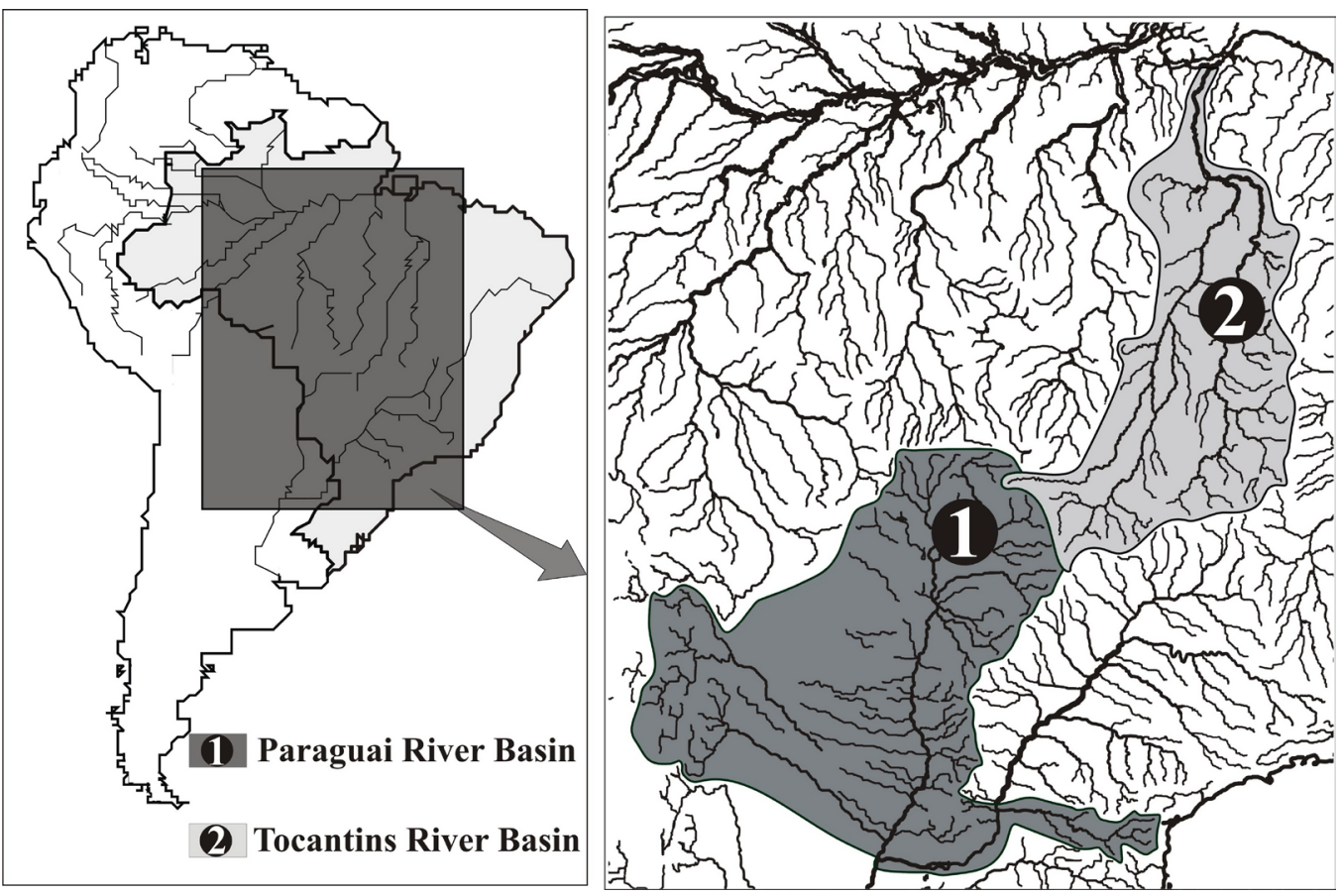

Figure 1. South America map indicating the sampling areas of Zungaro individuals. Numbers indicate sampling basins: 1 = Paraguay River basin, a sub-basin of Paraná-Paraguay River basin, where Manso River is located; $2=$ Tocantins River basin, a sub-basin of Amazon basin where Tocantins River is located. 
Total DNA of samples (from muscle tissues) was obtained based on the phenol/chlorophorm methodology (Monesi et al., 1998) and resuspended in $50 \mu \mathrm{L}$ TE diluted (1:10) buffer ( $1 \mathrm{mM}$ Tris-HCl, $\mathrm{pH} 8,0.1 \mathrm{mM}$ EDTA) with $20 \mu \mathrm{g} / \mathrm{mL}$ RNase. Fragments of mtDNA were amplified by PCR, using aliquots of the total DNA (Prioli et al., 2011). The first fragment of approximately $2000 \mathrm{bp}$ was amplified by the primers H1091 (5'-ATAGTGGGGTATCTAATCCAGTT-3') (Kocher et al., 1989) and L15774 (5'-CAACATGAATTGGAGGTATACCAGT-3') (Shields and Kocher, 1991). This fragment encompasses the tRNA ${ }^{\text {thr }}$ and tRNA $^{\text {Pro }}$ genes (responsible for codifying tRNA of threonine and proline amino acids, respectively) and a sequence of a hypervariable region $5^{\prime}$ of the heavy ribbon of the mtDNA control region (D-loop). The second fragment of approximately 1000 bp comprises gene codings for ATPase 6 and ATPase 8 subunits. This fragment was amplified by the primers H8331 (5'-AAAGCRTYRGCCTTTTAAGC-3') and L9236 (5'-GTTAGTGGTCAKGGGCTTGGRTC-3') (Hughes and Hillyer, 2006).

Both fragments were amplified in two independent reactions for further sequence determination and analysis, always using replicates. The reaction solution was composed of Tris$\mathrm{KCl}$ buffer ( $20 \mathrm{mM}$ Tris-HCl, $\mathrm{pH} 8.4,50 \mathrm{mM} \mathrm{KCl}), 1.5 \mathrm{mM} \mathrm{MgCl}, 2.5 \mu \mathrm{M}$ of each primer, $0.1 \mathrm{mM}$ of each dNTP, $2.5 \mathrm{U}$ Taq DNA polymerase per reaction, $30 \mathrm{ng}$ genomic DNA, and deionized and autoclave water was used to make a final volume of $25 \mu \mathrm{L}$. Amplifications of fragments were executed in a thermocycler through 40 cycles, with the following temperature profiles: an initial cycle of $4 \mathrm{~min}$ at $94^{\circ} \mathrm{C}$ followed by 40 cycles of $15 \mathrm{~s}$ at $94^{\circ} \mathrm{C}, 30 \mathrm{~s}$ at $59^{\circ} \mathrm{C}$ and $2 \mathrm{~min}$ at $72^{\circ} \mathrm{C}$, finishing with a 10 -min cycle at $72^{\circ} \mathrm{C}$.

Resulting fragments were once more amplified with the primers H8331 and L15774 (for ATPase 6 gene and D-loop regions, respectively). Approximately 50 ng DNA after each PCR was directly used in nucleotide sequencing reactions in an automatic sequencer MegaBace (Amersham), following manual instructions. Nucleotide sequences, shaped as a chromatogram, were aligned using CLUSTAL W (Thompson et al., 1994) and manually edited with the BIOEDIT software (Hall, 1999). Using similarity, D-loop sequences were confirmed with available accesses in the GenBank, whereas tRNAs were identified using the tRNAScan-SE software (Lowe and Eddy, 1997). The number of polymorphic nucleotides and $p$-distances (percentages of nucleotide differences) were calculated with the MEGA 4.0 software (Tamura et al., 2007). Matrices of $p$-distances, for both regions of the mitochondrial genome, were used to group analyses using the neighbor-joining algorithm. Bootstrap analyses were based on 1000 resamplings.

Phylogenetic analyses were executed by comparing individual pairs. Since the evolutionary meaning of DNA sequence deletions is poorly known (Nei and Kumar, 2000), sites with deletions were not considered in the analysis of each comparison.

PAUP 4.0 (Swofford, 2002) and Modeltest 3.7 (Posada and Crandall, 1998) softwares were used to select evolutionary models through Akaike information criterium (AICc) and Bayesian information criterium (BIC). Phylogenetic relationships among haplotypes were obtained using the PHYML software (Guindon and Gascuel, 2003) and expressed as dendrograms. The maximum likelihood procedure, based on 500 bootstraps, was combined with the model mentioned above. Dendrograms and $p$-distances were calculated only for D-loop and ATPase 6 subunit regions, given that the sequence encompassing tRNAs is a highly conserved region. For that region, we only searched for punctual nucleotide modifications.

Sequences from other fish species obtained in GenBank were selected to serve as comparison basis for Zungaro sequences in this study. Sequences were aligned and only the 
same base pairs used in Zungaro individuals for each region (D-loop or ATPase 6 gene regions) were compared among individuals selected in GenBank to ensure that analyses were reliable. In addition, only sequences available from articles published in Thompson-ISI indexed journals (http://www.webbofscience.com) were selected for comparison. GenBank access numbers of sequences used are listed in Table 1.

Table 1. D-loop control region of mtDNA sequence from two Siluriformes genera, Pseudobagrus and Hipostomus, and ATPase 6 gene region of mtDNA sequence from two Siluriformes genera of the Ariidae family, Potamarius and Cathorops, with their respective GenBank accession numbers.

\begin{tabular}{|c|c|c|c|}
\hline Species & Fragment & Genbank accession No. & Reference \\
\hline Pseudobagrus taeniatus & D-loop & AB097696 & Watanabe and Nishida (2003) \\
\hline Pseudobagrus aurantiacus & D-loop & AB097694 & Watanabe and Nishida (2003) \\
\hline Pseudobagrus nudiceps & D-loop & AB097693 & Watanabe and Nishida (2003) \\
\hline Pseudobagrus ichikawai & D-loop & AB097692 & Watanabe and Nishida (2003) \\
\hline Pseudobagrus tokiensis & D-loop & AB097691 & Watanabe and Nishida (2003) \\
\hline Hypostomus affinis & D-loop & AJ318358 & Montoya-Burgos (2003) \\
\hline Hypostomus punctatus & D-loop & AJ318357 & Montoya-Burgos (2003) \\
\hline Hypostomus commersoni & D-loop & AJ318356 & Montoya-Burgos (2003) \\
\hline Hypostomus nigromaculatus & D-loop & AJ318355 & Montoya-Burgos (2003) \\
\hline Hypostomus watwata & D-loop & AJ318352 & Montoya-Burgos (2003) \\
\hline Hypostomus plecostomus & D-loop & AJ318351 & Montoya-Burgos (2003) \\
\hline Hypostomus fonchii & D-loop & AJ318350 & Montoya-Burgos (2003) \\
\hline Hypostomus boulengeri & D-loop & AJ318344 & Montoya-Burgos (2003) \\
\hline Potamarius grandoculis & ATPase 6 & DQ990657 & Betancur et al. (2007) \\
\hline Potamarius nelson & ATPase 6 & DQ990656 & Betancur et al. (2007) \\
\hline Potamarius izabalensis & ATPase 6 & DQ990654 & Betancur et al. (2007) \\
\hline Cathorops tuyra & ATPase 6 & DQ990652 & Betancur et al. (2007) \\
\hline Cathorops hypophthalmus & ATPase 6 & DQ990651 & Betancur et al. (2007) \\
\hline Cathorops multiradiatus & ATPase 6 & DQ990650 & Betancur et al. (2007) \\
\hline Cathorops aguadulce & ATPase 6 & DQ990648 & Betancur et al. (2007) \\
\hline Cathorops arenatus & ATPase 6 & DQ990647 & Betancur et al. (2007) \\
\hline Cathorops spixii & ATPase 6 & DQ990646 & Betancur et al. (2007) \\
\hline Cathorops steindachneri & ATPase 6 & DQ990644 & Betancur et al. (2007) \\
\hline Cathorops fuerthii & ATPase 6 & DQ990641 & Betancur et al. (2007) \\
\hline Cathorops dasycephalus & ATPase 6 & DQ990639 & Betancur et al. (2007) \\
\hline
\end{tabular}

Analyses were made on the D-loop region of two Siluriformes genera, Pseudobagrus (with five species) and Hypostomus (with eight species). Considering the ATPase 6 gene region, two other Siluriformes genera from the Ariidae family were used: Potamarius (with three species) and Cathorops (with nine species). All individual names were checked in the FishBase database (Froese and Pauly, 2007) to avoid comparisons between synonym species. The review by Marceniuk and Menezes (2007) was used for individuals from the Ariidae family. According to these authors, Potamarius usumacintae is synonym of $P$. grandoculis, and the last name should be used. Therefore, we used the $P$. usumacintae sequence (indicated at GenBank) but with the correct species name (P. grandoculis).

\section{RESULTS}

The Zungaro sequences used here were added to GenBank database (see access numbers in Table 2). By amplifying D-loop fragments, two sequences were selected for analyses, the first comprising the control region of D-loop ( $\sim 355 \mathrm{bp})$ and the second corresponding to tRNA $^{\text {Thr }}$ and tRNA ${ }^{\text {Pro }}$ genes $(140 \mathrm{bp})$ (Table 2). The main reason for choosing these sequences was their location at the best quality segment in the whole sequence (after manual edition). 
Despite being short sequences compared to the total fragments amplified (ca. $2000 \mathrm{bp}$ for Dloop region), this strategy was used for high rigor analysis and to avoid misinterpretations, thus enhancing reliability of the results. In addition, the selected sequence was sufficient to discriminate populations (see below). After aligning, two nucleotide substitution points were identified in tRNAs sequences, discriminating individuals of different sampling sites.

Table 2. Zungaro individuals, their sampling sites and GenBank accession numbers (AN) for both D-loop control region and ATPase 6 gene region.

\begin{tabular}{llcc}
\hline Zungaro individuals & Sampling site & D-loop AN & ATPase 6 AN \\
\hline ZgrMS01 & Manso River (Paraná-Paraguay River basin) & - & FJ794946 \\
ZgrMS02 & Manso River (Paraná-Paraguay River basin) & - & FJ794947 \\
ZgrMS03 & Manso River (Paraná-Paraguay River basin) & - & FJ794948 \\
ZgrMS04 & Manso River (Paraná-Paraguay River basin) & FJ797691 & FJ794955 \\
ZgrMS05 & Manso River (Paraná-Paraguay River basin) & FJ797692 & FJ794956 \\
ZgrMS06 & Manso River (Paraná-Paraguay River basin) & FJ797693 & FJ794950 \\
ZgrMS07 & Manso River (Paraná-Paraguay River basin) & - & FJ794951 \\
ZgrMS08 & Manso River (Paraná-Paraguay River basin) & - & FJ794952 \\
ZgrMS09 & Manso River (Paraná-Paraguay River basin) & FJ797694 & FJ794953 \\
ZgrMS10 & Manso River (Paraná-Paraguay River basin) & - & FJ794954 \\
ZgrMS11 & Manso River (Paraná-Paraguay River basin) & FJ797695 & FJ794957 \\
ZgrTo02 & Tocantins River (Amazon basin) & FJ797696 & FJ794958 \\
ZgrTo03 & Tocantins River (Amazon basin) & FJ797697 & FJ794959 \\
ZgrTo04 & Tocantins River (Amazon basin) & - & FJ794960 \\
ZgrTo05 & Tocantins River (Amazon basin) & FJ794961 \\
ZgrTo06 & Tocantins River (Amazon basin) & & \\
\hline
\end{tabular}

Considering the D-loop region, sequences revealed 19 substitution points, 15 transversions and four transitions. This rate $(\mathrm{R}=$ transversions/transitions $=3.75)$ corroborates with expectations for the fragment corresponding to the D-loop region (Nei and Kumar, 2000). Individuals from Tocantins River presented an insertion of a cytosine and 16 substitutions. The polymorphisms of the D-loop region among Manso individuals, using pairwise comparisons, were always up to one polymorphic site $(p$-distance $=$ $0.3 \%)$. When Manso individuals were compared to Tocantins ones, 16-17 polymorphic sites were found ( $p$-distances $=4.5-4.8 \%)$.

The values of D-loop region polymorphic sites for some species from different Siluriformes genus, Pseudobagrus and Hypostomus, were at the same level with those obtained for the same D-loop region from Zungaro of Manso and Tocantins Rivers. Similar values were also observed in half the relationships among Pseudobagrus species ( $p$ distances up to $5.0 \%$ ). The differentiation of Zungaro haplogroups from Manso and Tocantins Rivers was sometimes clearer than the differentiation of species from Hypostomus and Pseudobagres genus, considering the dendrogram constructed with $p$-distance values of the D-loop region (Figure 2). This dendrogram grouped Zungaro individuals according to sampling rivers, with a bootstrap of $100 \%$. The dendrogram constructed using evolutionary models displayed a similar pattern and therefore was omitted.

Considering that the ATPase 6 gene region is more preserved, few differences were observed between related groups. A good-quality sequence of $204 \mathrm{bp}$ (edited from an amplified fragment of ca. $1000 \mathrm{bp}$ ) was selected for analysis (see reasons for editing sequences above). Five nucleotide substitutions between individuals from the two rivers (Manso and Tocantins Rivers) were found. Individuals of the same river always had the 
same nucleotide sequence. This partial ATPase 6 gene sequence corresponds to 68 amino acids. Despite these nucleotidic differences, no amino acid substitution was evidenced considering the previewed polypeptide.

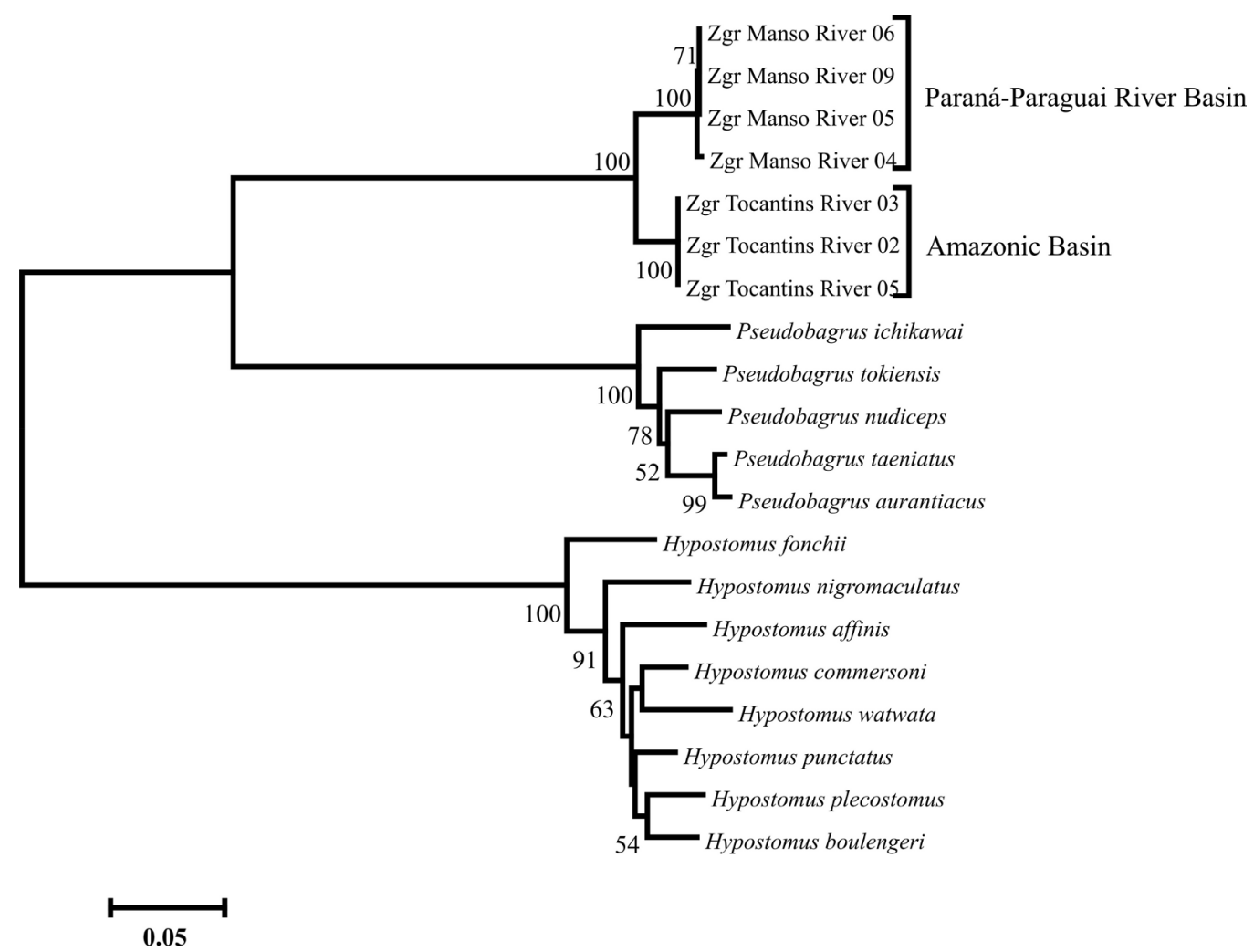

Figure 2. Neighbour joining tree based on $p$-distances of partial D-loop nucleotidic sequences of mitochondrial DNA from eight Hypostomus species, five Pseudobagrus species and Zungaro (Zgr) individuals sampled in Manso and Tocantins Rivers, with a bootstrap of $100 \%$. Sequences of Hypostomus and Pseudobagrus species were obtained in GenBank.

The differentiation between haplotypes from Paraná-Paraguay River and Amazon basins represents a $p$-distance of $2.5 \%$. This value is higher than those found to differentiate three Siluriformes species of the Potamarius genus (P. grandoculis, P. nelson, and P. izabalensis), and similar to some $p$-distances between Siluriformes species of the Cathorops genus. Values of $p$-distances between species of Cathorops genus were highly variable, varying from $1.5 \%$ (between $C$. spixii and C. arenatus) to $17.6 \%$ (between $C$. dasycephalus and $C$. hypophthal$m u s$ ). Differences observed when comparing Zungaro individuals from both rivers were higher than those observed for Potamarius species considering the dendrogram constructed with $p$-distance values of the ATPase 6 region (Figure 3). In addition, these differences were at the same level of those observed for some Cathorops species (Figure 3). Once more, the dendrogram constructed using evolutionary models was similar and, therefore, omitted. 


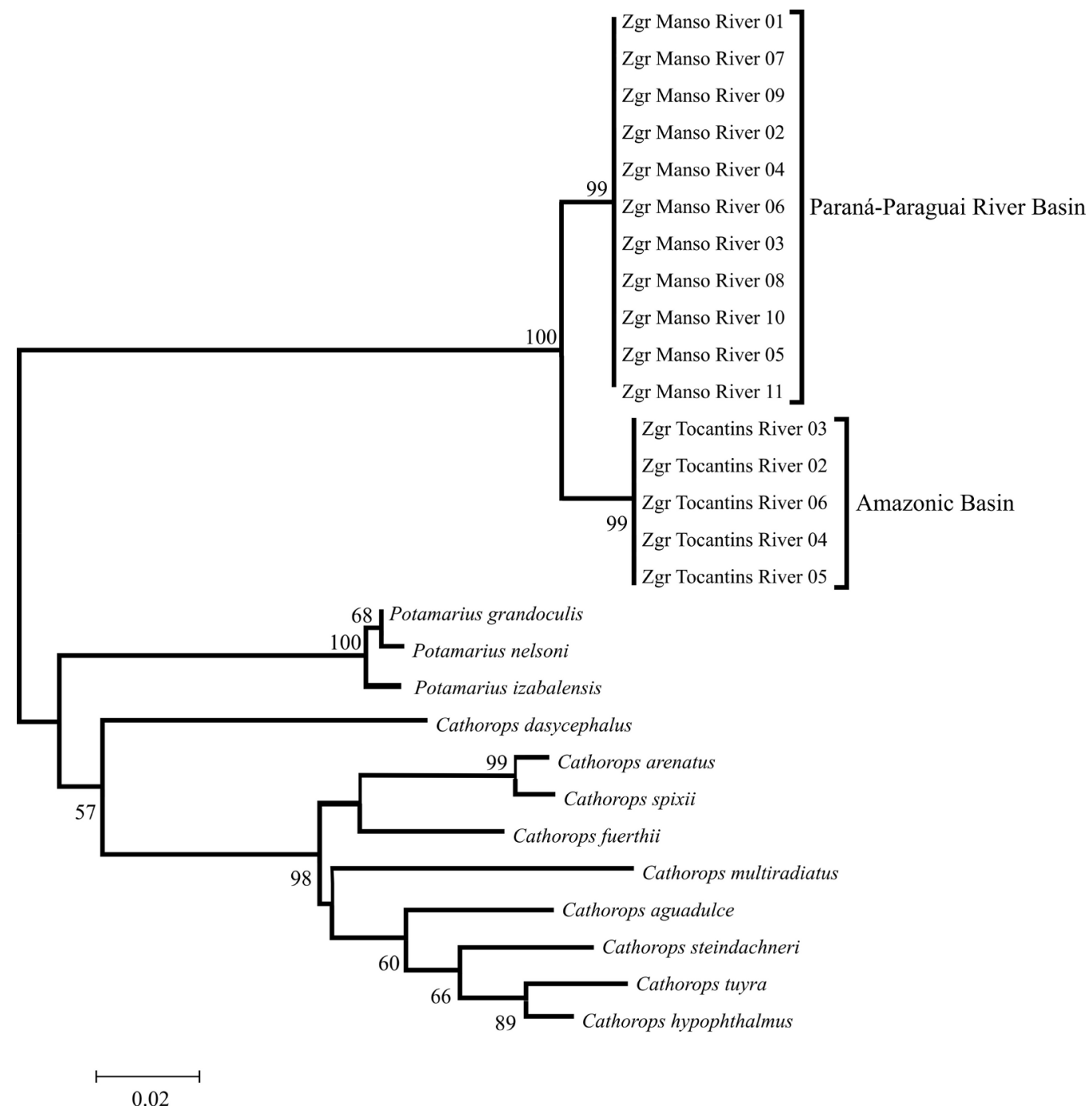

Figure 3. Dendrogram constructed using $p$-distances of partial ATPase 6 nucleotidic sequences from nine Cathorops species, three Potamarius species and Zungaro (Zgr) individuals sampled in Manso and Tocantins Rivers, with a bootstrap of $100 \%$. Sequences of individuals from Cathorops and Potamarius genus were obtained in GenBank.

\section{DISCUSSION}

The taxonomy of indigenous Zungaro populations in Brazil still shows discrepancies to be solved. Previous studies have morphologically identified two different species of Zungaro from the Paraná-Paraguay River and Amazon basins (Lundberg and Littmann, 2003). However, a taxonomic review considered that $Z$. zungaro is the only species in Brazil (e.g., Graça and Pavanelli, 2007). Overall, our results support the suspicion that Zungaro 
individuals from the Paraná-Paraguay River and Amazon basins represent two distinct taxa. They possibly belong to closely related species, but not to the same species. Further taxonomic studies are necessary to conclude on the taxonomy of this genus.

The analysis of ATPase 6 fragment from Zungaro indicated a low magnitude of differences, when compared to D-loop sequences. This finding was expected a priori since D-loop region is highly variable. Therefore, both intra- and interspecific differences should be low (Avise, 2004). Even so, genetic distances between individuals from Paraná-Paraguay River and Amazon basins were of the same level as those of differentiate related species from other Siluriformes genera. In fact, other studies using mtDNA have reported similar levels of differentiation between related species (Oliveira et al., 2006; Samonte et al., 2007).

Even with a consistent genetic distance, there is a phylogenetic proximity between Zungaro individuals from the Paraná-Paraguay River and Amazon basins, due to equal nucleotidic sequences of tRNA ${ }^{\text {Pro }}$ and tRNA ${ }^{\text {Thr }}$ mitochondrial genes. This is an expected result for individuals of related species. In fact, identical sequences of tRNA ${ }^{\text {Pro }}$ gene were found among A, C and D cytotypes of Hoplias aff. malabaricus (Perioto, 2004). It is clear that the cytotypes of $H$. aff. malabaricus are distinct, although undescribed, species (Perioto, 2004).

The genetic differentiation and high morphologic similarity of Zungaro individuals analyzed here can be explained by the origin of the populations. The separation of both the Paraná-Paraguay River and Amazon basins occurred in Late Miocene, in the last $10 \mathrm{Ma}$ (Hubert and Renno, 2006). Therefore, during the formation of the two basins, the definitive separation of two Zungaro populations was possible through vicariance. After this event, genetic differentiation would initiate. However, there is some capture of Zungaro individuals in the source streams of the Paraná-Paraguay River and Amazon basins (Räsänen et al., 1995), where little and temporary communication exists even after the establishment of these two macro-basins. Therefore, populations could possibly migrate across basins during wet seasons. An original population of the Amazon basin could have colonized the Paraná-Paraguay River basin after dispersion via source streams. However, at some specific time, genetic flux between Zungaro populations must have been interrupted, and populations from different basins were isolated through vicariance. This hypothesis seems possible given that accumulated genetic differences are, apparently, in much lower levels than those expected for a period of $10 \mathrm{Ma}$, corresponding to the separation of the Paraná-Paraguay River and Amazon basins (Hubert and Renno, 2006).

Independently of the mechanism, the magnitude of differences found between individuals suggests that Zungaro populations from the Paraná-Paraguay River and Amazon basins have been geographically isolated for a sufficient amount of time for speciation to occur. The accentuated geographic pattern in distribution of the haplotypes was evidenced in all constructed trees relating individuals from the two basins. Therefore, the suspicion that the Zungaro species from the Paraná-Paraguay River basin does not identify with the species encountered in the Amazon basin deserves a detailed taxonomic investigation. Our findings are extremely relevant, since this fish is highly threatened in the Paraná-Paraguay River basin (Okada et al., 2005; Alves, 2006), and the introduction of Zungaro individuals from the Amazon basin may not be a valid re-population effort. If Zungaro from Amazon is introduced in the Paraná-Paraguay River basin, native populations can decay even more due to competition. Moreover, given that Zungaro from different River basins seems to be closely related species, hybrids can be generated, affecting the genetic structure of native populations of this fish. Therefore, conservation efforts should be urgently improved due to the possible existence of 
an endemic and highly threatened species of Zungaro in the Paraná-Paraguay River basin. In fact, the recent impoundments in this basin are contributing to the rapid population decrease of migratory fish, such as Zungaro species (Okada et al., 2005; Pelicice and Agostinho, 2008). When hydropower dams are constructed, fish ladders can not be fully effective to conserve populations of migratory fish (Pelicice and Agostinho, 2008). The protection and restoration of critical habitats in those sub-basins of the Paraná-Paraguay River basin still free from damming seems to be the best conservation strategy (Pelicice and Agostinho, 2008). Furthermore, other studies on the genetic diversity of this species within locations of the Paraná-Paraguay River basin are fundamental to subsidize management efforts aiming at the recovery of natural populations of Zungaro species.

\section{ACKNOWLEDGMENTS}

We acknowledge NUPELIA (Maringá State University) for financial and logistical support, "FURNAS Centrais Elétricas" for samplings carried out in Manso River, Dr. Carlos S. Agostinho for samplings carried out in Tocantins River, Prof. João Marcelo Boni for English revision, and CNPq-PELD for financial support. T.A. Boni, L.C. Lúcio, T.C. Maniglia, and A. Padial also acknowledge CAPES for scholarship grants. We also acknowledge anonymous reviewers for valuable suggestions in previous drafts of this paper.

\section{REFERENCES}

Agnese JF, Adepo-Gourene B, Abban EK and Fermon Y (1997). Genetic differentiation among natural populations of the Nile tilapia Oreochromis niloticus (Teleostei, Cichlidae). Heredity 79: 88-96.

Agostinho AA, Gomes LC, Suzuki HI and Júlio HF Jr (2003). Migratory Fishes of the Upper Paraná River Basin. In: Migratory Fishes of South America: Biology, Fisheries and Conservation Status (Carolsfeld J, Harvey B, Ross C and Baer A, eds.). World Fisheries Trust-The World Bank, Ottawa, 19-98.

Alves CBM (2006). Jaú (Zungaro jahu): Um Peixe mais Ameaçado que os Outros? Boletim Sociedade Brasileira de Ictiologia, João Pessoa, 4-5.

Avise JC (2004). Molecular Markers, Natural History, and Evolution. 2nd edn. Sinauer Associates Inc. Publisher, Sundeland.

Azevedo MFC, Oliveira C, Pardo BG, Martínez P, et al. (2008). Phylogenetic analysis of the order Pleuronectiformes (Teleostei) based on sequences of 12S and 16S mitochondrial genes. Genet. Mol. Biol. 31: 284-292.

Betancur R, Acero PA, Bermingham E and Cooke R (2007). Systematics and biogeography of New World sea catfishes (Siluriformes: Ariidae) as inferred from mitochondrial, nuclear, and morphological evidence. Mol. Phylogenet. Evol. 45: 339-357.

Britski HA, Silimon KZS and Lopes BS (2007). Peixes do Pantanal: Manual de Identificaçäo. $2^{\mathrm{a}}$ ed. Embrapa, Brasília.

Ferraris CJ (2007). Checklist of catfishes, recent and fossil (Osteichthyes: Siluriformes), and catalogue of siluriform primary types. Zootaxa 1418: 1-628.

Froese R and Pauly D (2007). FishBase. World Wide Web Electronic Publication. Available at [www.fishbase.org.]. Accessed October, 2008.

Graça WJ and Pavanelli CS (2007). Peixes da Planície de Inundação do Alto Rio Paraná e Áreas Adjacentes. EDUEM Editora da Universidade Estadual de Maringá, Maringá.

Guindon S and Gascuel O (2003). A simple, fast, and accurate algorithm to estimate large phylogenies by maximum likelihood. Syst. Biol. 52: 696-704.

Hall TA (1999). BioEdit: a user-friendly biological sequence alignment editor and analysis program for Windows 95/98/ NT. Nucleic Acids Symp. Ser. 41: 95-98.

Hubert N and Renno JF (2006). Historical biogeography of South American freshwater fishes. J. Biogeog. 33: 1414-1436.

Hughes JM and Hillyer MJ (2006). Mitochondrial DNA and allozymes reveal high dispersal abilities and historical movement across drainage boundaries in two species of freshwater fishes from inland rivers in Queensland, Australia. J. Fish Biol. 68: 270-291. 
Johns GC and Avise JC (1998). A comparative summary of genetic distances in the vertebrates from the mitochondrial cytochrome b gene. Mol. Biol. Evol. 15: 1481-1490.

Kocher TD, Thomas WK, Meyer A, Edwards SV, et al. (1989). Dynamics of mitochondrial DNA evolution in animals: amplification and sequencing with conserved primers. Proc. Nat. Acad. Sci. U. S. A. 86: 6196-6200.

López HL, Miquelarena AM and Ponte Gómez J (2005). Biodiversidad y distribución de la ictiofauna Mesopotámica. Miscelánea 14: 311-354.

Lowe TM and Eddy SR (1997). tRNAscan-SE: a program for improved detection of transfer RNA genes in genomic sequence. Nucleic Acids Res. 25: 955-964.

Lundberg JG and Littmann MW (2003). Família Pimelodidae. In: Check List of the Freshwater Fishes of South and Central America (Reis RE, Kullander SO and Ferraris SJ, eds.). EDIPUCRS, Porto Alegre, 432-446.

Marceniuk AP and Menezes NA (2007). Systematics of the Family Ariidae (Ostariophysi, Siluriformes), with a Redefinition of the Genera. Zootaxa 1416, Magnolia Press, New Zealand.

Meyer A (1994). DNA Technology and Phylogeny of Fish. In: Genetics and Evolution of Aquatic Organisms (Beaumont AR, ed.). Chapman \& Hall, London, 219-249.

Monesi N, Jacobs-Lorena M and Paçó-Larson ML (1998). The DNA puff gene BhC4-1 of Bradysia higida is specifically transcribed early prepupal salivary glands of Drosophila melanogaster. Chromosoma 10: 559-569.

Montoya-Burgos JI (2003). Historical biogeography of the catfish genus Hypostomus (Siluriformes: Loricariidae), with implications on the diversification of Neotropical ichthyofauna. Mol. Ecol. 12: 1855-1867.

Nei M and Kumar S (2000). Molecular Evolution and Phylogenetics. Oxford University Press Inc., New York.

Okada EK, Agostinho AA and Gomes LC (2005). Spatial and temporal gradients in artisanal fisheries of a large Neotropical reservoir, the Itaipu Reservoir, Brazil. Can. J. Fish. Aquat. Sci. 62: 714-724.

Oliveira AV, Prioli AJ, Prioli SMAP and Bignotto TS (2006). Genetic diversity of invasive and native Cichla (Pisces: Perciformes) populations in Brazil with evidence of interspecific hybridization. J. Fish Biol. 69: 260-277.

Ortí G, Sivasundar A, Dietz K and Jégu M (2008). Phylogeny of the Serrasalmidae (Characiformes) based on mitochondrial DNA sequences. Genet. Mol. Biol. 31: 343-351.

Pelicice FM and Agostinho AA (2008). Fish-passage facilities as ecological traps in large Neotropical rivers. Conserv. Biol. 22: 180-188.

Perioto PS (2004). Variabilidade Genética do Complexo Hoplias aff. malabaricus Acessada com Marcadores Moleculares Nucleares e Mitocondriais. Doctoral thesis, Universidade Estadual de Maringá, Maringá.

Posada D and Crandall KA (1998). MODELTEST: testing the model of DNA substitution. Bioinformatics 14: 817-818.

Prioli SMAP, Prioli AJ, Júlio HF Jr, Pavanelli CS, et al. (2011). Identification of Astyanax altiparanae (Teleostei, Characidae) in the Iguaçu River, Brazil, based on mitochondrial DNA and RAPD markers. Genet. Mol. Biol. 25: 421-430.

Räsänen ME, Linna AM, Santos JCR and Negri FR (1995). Late miocene tidal deposits in the Amazonian foreland basin. Science 269: 386-390.

Rokas A, Ladoukakis E and Zouros E (2003). Animal mitochondrial DNA recombination revisited. Trends Ecol. Evol. 18: 411-417.

Samonte IE, Satta Y, Sato A, Tichy H, et al. (2007). Gene flow between species of Lake Victoria haplochromine fishes. Mol. Biol. Evol. 24: 2069-2080.

Shields GF and Kocher TD (1991). Phylogenetic relationships of North American ursids based on analysis of mitochondrial DNA. Evolution 45: 218-221.

Swofford DL (2002). PAUP: Phylogenetic Analysis Using Parsimony and other Methods Version 4. Sinauer Associates Inc. Publisher, Sundeland.

Tamura K, Dudley J, Nei M and Kumar S (2007). MEGA4: molecular evolutionary genetics analysis (MEGA) software version 4.0. Mol. Biol. Evol. 24: 1596-1599.

Thompson JD, Higgins DG and Gibson TJ (1994). CLUSTAL W: improving the sensitivity of progressive multiple sequence alignment through sequencing weighting, position-specific gap penalties and weight matrix choice. Nucleic Acids Res. 22: 4673-4680.

Torres RA and Ribeiro J (2009). The remarkable species complex Mimagoniates microlepis (Characiformes: Glandulocaudinae) from the Southern Atlantic Rain forest (Brazil) as revealed by molecular systematic and population genetic analyses. Hydrobiologia 617: 157-170.

Watanabe K and Nishida M (2003). Genetic population structure of Japanese bagrid catfishes. Ichthyol. Res. 50: 140-148. 